\title{
Blended Learning to Improve the Students' Vocabulary Mastery for Mechanical Engineering Purposes at STT Adisutjipto Yogyakarta
}

\author{
Dewanti Ratna Pertiwi \\ STT Adisutjipto
}

\begin{abstract}
The study was conducted to improve the low vocabulary mastery of technical terms appeared in English for mechanical engineering purposes at STT Adisutjipto. The students are required to master the technical terms of the three offered concentrations; energy conversion, aircraft maintenance, and manufacture. A blended learning was chosen to improve the students' vocabulary mastery through an action research study. It was divided in two cycles and the data were collected through the journal log, observation sheet, questionnaire, test, and interview. The result indicated that the students enjoyed and improved their vocabulary mastery. The blended learning was seen effectively improving the vocabulary mastery.
\end{abstract}

Keywords: blended learning, mechanical engineering, vocabulary

\section{INTRODUCTION}

One of the important aspects of learning English is mastering vocabulary. It will affect the students' ability in developing the four language skills (Read, 2004). Based on the observation the students found difficulties in mastering technical vocabulary. In the group presentation about mechanical engineering discussions topics they read notes, were lack of confidence and felt hesitate to express their idea, e.g. in describing the functions of a basic aircraft structure.

The low vocabulary mastery is a crucial problem needs to be improved since the students have to be able to identify the English technical terms of the three offered concentrations in mechanical engineeringenergy conversion, aircraft maintenance, and manufacture. Basturkmen (2006) says that ESP is purposively conducted to gain specific language and performance competencies target in the workplace, academic, and professional development.

The English environment and less opportunity to master their vocabulary are predicted as the main reasons for this low vocabulary mastery. Changing the curriculum policy needs longer procedures. ICT emerges to offer an innovation in English instructional technology. In addition, the students are Internet literate and well facilitated with technology. Edmodo platform is chosen for its simple menu, sufficient facilities, accessible software, and interactive respond. Charoenwet \& Christensen (2016) report that Edmodo was created by Nic Borg and Jeff O'Hara eight years ago as the educational media networking. It has students' progress, library, notes, assignment, quiz, polls, schedule, and snapshot.

This research is expected to contribute to the mechanical engineering study program as an input of reference relating to the technique to improve vocabulary mastery for English for Specific Purposes. Furthermore, to other researchers who wish to develop ICT learning for mechanical engineering purposes or other subjects, the result may be the reference as how the ICT learning is designed.

There are various ways of ICT conducted in English instructional. According to Azizan (2010), a total online learning and face to face have some weaknesses and strengths, therefore it is better to modify both into a blended instruction. In addition, Lim \& Morris (2009) argue that blended learning is advantageous to facilitate various teaching techniques and improve learners' satisfaction and learning outcomes.

Description of the keywords are interpreted. Djiwandono (2013) says blended learning is simply explained as the combination of conventional face to face learning with online instructional activity through the Internet. It emerges as the extension of ICT learning in which the language instructor is enhanced with 
resourceful materials and tools to develop more interactive and attractive instruction. Then, mechanical engineering is employed to practice the English for Specific Purposes especially English for academic purposes. The Website of Columbia University defines mechanical engineering as "a diverse subject that derives its breadth from the need to design and manufacture everything from small individual parts and devices to large systems". Thirdly, Nation (2001) summarizes based on the purposes, vocabulary in ESP is divided into three; technical, semi-technical, and general vocabulary. This study employed all categories of ESP vocabulary to broaden the students' knowledge. Nevertheless, based on the Bloom Taxonomy, the operational measurement indicator is limited on the first three level, i.e. remember, understand, and apply.

There are two research studies discussed. Khalili, Tahririan, \& Bagheri (2015) conducted a study on "Vocabulary Instruction through Blended Learning and Multimedia Software in Iranian ESP Classes". 120 ESP learners were involved in the experimental study. The result indicated the great level of improvement in vocabulary mastery using blended learning. On the other hand, Arfaorafiee \& Ameri-Golestan (2015) conducted a study on "Impact of Blended Learning on Iranian EFL Learners' Acquisition and Retention of Passive Sentences" involving 44 EFL learners. The result indicated there was no significant difference between the students taught using traditional technique and using the blended learning due to the less literate learners to the technology.

A blended learning is going to be designed to improve the students' vocabulary mastery. Thus, this research is intended to answer the problem formulation of 'How does the blended learning improve students' vocabulary mastery for mechanical engineering purposes?' to give evidence that blended learning can facilitate the students' vocabulary mastery improvement.

\section{RESEARCH METHOD}

The study was conducted in Mechanical Engineering Study Program, STT Adisutjipto, Yogyakarta. This is one of the private colleges under the foundation organized by the air force retired men. The main characteristic is the students are given some subjects with aerospace-based learning including the mechanical engineering study program.

The study involved two classes of the 2016 year graders with 80 students. $93 \%$ are male and $7 \%$ are female students. They are Internet literate and well facilitated with the Internet connection. Because the students are very heterogeneous, the researcher grouped them into three to ease the tasks more suitable to their competence into group A (fast learner), B (slow learner), and C (mixed). The research was executed in Semester II of academic year 2016/2017.

As the goal of this study is to investigate how certain technique improves a problem, an action research (AR) was employed. Tomal (2010) explains that the researcher in action research is concerned in using systematic process in solving educational cases and triggered to find the solution. In addition, Burns (2010) supports that AR is a critical, reflective teaching, followed by a systematic approach to solve the existing problems in the instructional program. The central idea of AR is deliberating way in the problematic situation to bring changes, better quality, and practical improvement. The data incorporated both qualitative and quantitative data formulized from some sources, i.e. the journal log, observation sheet, questionnaire, test, and interview.

In order to conduct a thorough action research, research instruments are consulted. The instruments adapted from McNiff, Lomax, \& Whitehead (2002) and Henning, Stone, \& Kelly (2009). The first instrument is journal-log that is the columns for writing comments on the students' activities. The second instrument is observation sheet that helps the lecturer to make improvement in teaching-learning process. The third instrument is the interview purposed to identify the problems occur in the classroom and identify the respond and opinion on the use of blended learning. The fourth is comparing the students' achievement before and after being given the blended learning i.e. marks in the mid-term test, the performance in the workshop visit, and the written test. The last instrument is distributing questionnaire after AR to investigate the students' opinion and respond to the use of blended learning. 
The procedures of conducting the research were as follows:

Cycle I

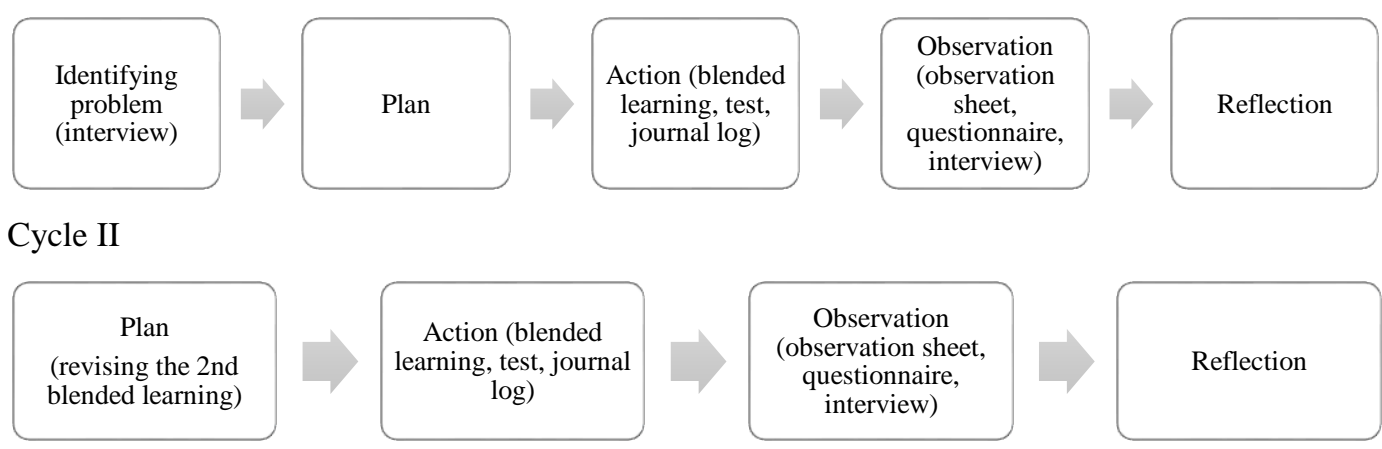

Figure 1. The Procedures of Action Research (AR)

The analysis is done considering all instruments responses, reflecting the positive and negative responses to the blended learning to see the improvement of the English instruction. The qualitative data from the interview, journal log, and observation sheet were analyzed to confirm the general major students' experience, perception and thoughts about the given action (blended learning). Meanwhile, the quantitative data from the questionnaire were seen how the data numbers supported the qualitative data and from the test were seen how the achievement increased.

\section{RESULTS AND ANALYSIS}

\subsection{Cycle 1}

\section{a. Identifying problem}

Before executing the plan step, the problematic educational issue was identified by interviewing the students. The objects were the representative students of those achieved low (C), middle (B), and high (A) mark in the mid-term test in a hope they were able to figure out the problems experienced related to the low vocabulary mastery.

Table 1. Most Frequent Responses on a Crucial Problem of Vocabulary Mastery

\begin{tabular}{cl}
\hline No. & Responses \\
\hline 1. & The English subject schedule is limited to master sufficient technical terms \\
2. & Technical terms constrain the students to communicate \\
3. & The English workbook sometimes does not give clear description on certain technical terms \\
4. & The students feel shy to ask the meaning of difficult technical terms \\
5. & Interactive media are needed to support the vocabulary mastery. \\
\hline
\end{tabular}

From the interview, it could be summarized two main causes restricted the low vocabulary development. The first, the opportunity limited the students' chance to develop their vocabulary mastery. In fact, two credits allocated in semester two which is distributed into fourteen meetings was seen insufficient to master the mechanical engineering technical terms. The second, the learning media did not support the vocabulary development. The English workbook used was from the developed country publisher that did not have a clear description of certain terms requiring a lot of adaptations. Moreover, the conventional teaching media were seen less interesting to support the vocabulary mastery.

\section{b. Plan}

Following up the interview, a set of blended learning was proposed. A series of activities were given to the students by grouping. The first online activity was given to prepare the students with the materials would be tested in the face to face activity that they had more time to access other sources to support the 
materials. Some online tasks were delivered to the slow and fast learners separately that they might proceed their vocabulary development. The first face to face activity was intended to check the vocabulary mastery classically (mixed of the slow and fast learners), give them an opportunity to discuss the problems they might face in the online tasks, and prepare the project would be assessed in the second face to face activity.

In the second online one, series of activities were delivered to the slow and fast learners separately as the vocabulary drilling. In the second face to face activity, the students' vocabulary mastery was assessed by their performance in the mechanical engineering workshop visit. They were assessed individually in describing the material types and properties existed.

\section{c. Action}

In this step, blended learning was applied. Here is the distribution of face to face activity and online activity.

Table 2. Action of Cycle 1

\begin{tabular}{|c|c|}
\hline $\begin{array}{l}\text { Class } \\
\text { Online activity }\end{array}$ & $\begin{array}{c}\text { Group } \\
\text { A (fast), B (slow), C (mix) }\end{array}$ \\
\hline Text 1 & $\mathrm{C}$ \\
\hline Video 1 & $\mathrm{C}$ \\
\hline Vocabulary task 1 & A \\
\hline Vocabulary task 2 & $\mathrm{~B}$ \\
\hline Vocabulary task 3 & $\mathrm{~B}$ \\
\hline Face to face activity & $\mathrm{C}$ \\
\hline Course introduction & $\mathrm{C}$ \\
\hline Text 2 & $\mathrm{C}$ \\
\hline Dictionary use & $\mathrm{C}$ \\
\hline Learning definition of technical terms & $\mathrm{C}$ \\
\hline Face to face Tasks (vocabulary, reading comprehension in Text 2) & $\mathrm{C}$ \\
\hline Feedback on the face to face tasks & $\mathrm{C}$ \\
\hline $\begin{array}{l}\text { Discussing the following project: preparing Workshop Visit (visiting the } \\
\text { campus laboratory of mechanical engineering. The students should be } \\
\text { ready to describe types and properties materials exist in the laboratory) }\end{array}$ & $\mathrm{C}$ \\
\hline \multicolumn{2}{|l|}{ Online activity } \\
\hline Text 3 & $\mathrm{C}$ \\
\hline Vocabulary task 4 & A \\
\hline Vocabulary task 5 & $\mathrm{~B}$ \\
\hline Vocabulary task 6 & $\mathrm{~B}$ \\
\hline \multicolumn{2}{|l|}{ Text 4} \\
\hline Vocabulary task 7 & A \\
\hline Vocabulary task 8 & $\mathrm{~B}$ \\
\hline Vocabulary task 9 & $\mathrm{~B}$ \\
\hline \multicolumn{2}{|l|}{ Text 5} \\
\hline Vocabulary task 10 & $\mathrm{C}$ \\
\hline Vocabulary task 11 & $\mathrm{C}$ \\
\hline \multicolumn{2}{|l|}{ Face to face activity } \\
\hline $\begin{array}{l}\text { Students' workshop visit and practice in describing the types of materials } \\
\text { and the property. }\end{array}$ & $\mathrm{C}$ \\
\hline $\begin{array}{l}\text { Discussing the following program: the students should be ready with the } \\
\text { written quiz on material types and material property. }\end{array}$ & $\mathrm{C}$ \\
\hline
\end{tabular}

To investigate the improvement, comparing the previous condition with after Action treatment was done. In this case, the comparison of Mid-Term Test mark and the performance mark in workshop visit are presented as follows. 


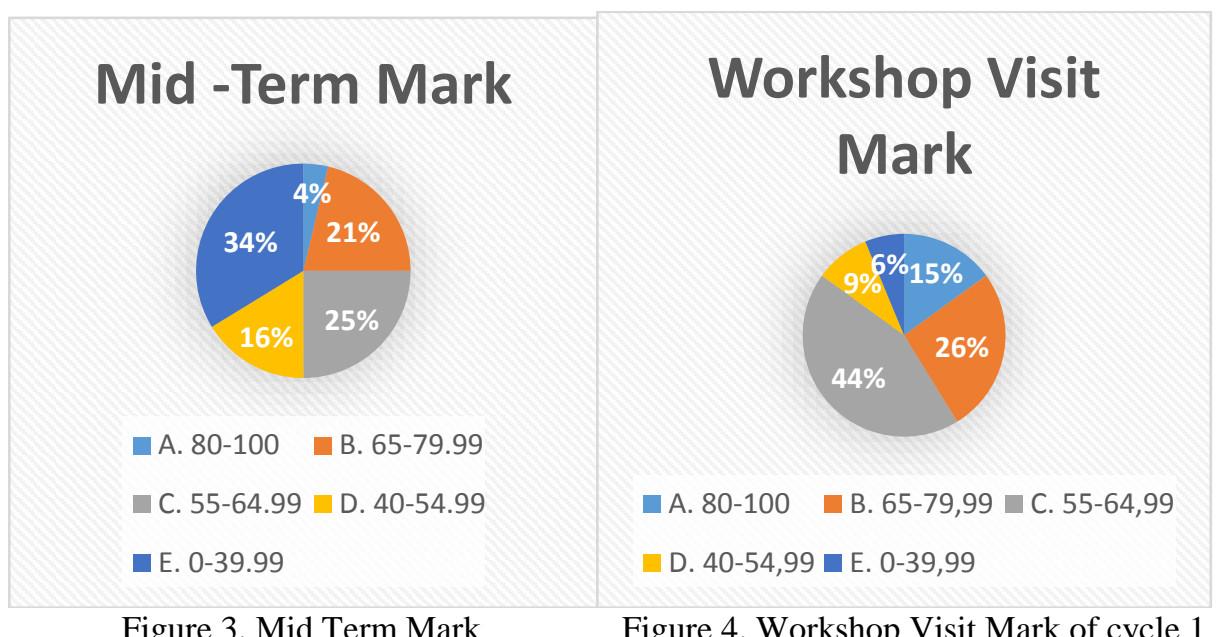

Figure 3. Mid Term Mark

Figure 4. Workshop Visit Mark of cycle 1

The graphs showed that there was an improvement in the students' mark.

During the Action, the students were given journal logs to write their comments in experiencing the blended learning. The logs were taken home to write the more thorough response as presented here.

Table 3. Journal Log of Cycle 1

\begin{tabular}{ll}
\hline No. & \multicolumn{1}{c}{ Responses } \\
\hline 1. The students felt excited being blended into the online learning but still need to familiarize on \\
the icons and facilities of Edmodo \\
2. The students learned technical terms often used in discussing material types and the properties \\
through video, linked article, and quizzes \\
3. The students got low mark in the first online quiz because unfamiliar yet with the instruction and \\
the icon \\
4. The students improved the following online quiz mark because they have been familiar with the \\
5. The struction and the icon \\
visit.
\end{tabular}

The journal log presented positive perceptions on the blended learning. It was proven that the students felt excited being blended to the online and face to face activity even though some problems still occurred due to the new application they had in the online activity. They were eager to improve their vocabulary mastery that they got the better mark in the in the following online activity.

\section{d. Observation}

In the observation step, the effects of the blended learning were investigated from observation sheet, questionnaire, and the second interview. Some notes found during the observation, the questionnaire, and the interview are as follows.

Table 4. Observation of Cycle 1

\begin{tabular}{cl}
\hline No. & Findings \\
\hline 1. & The students felt curious on the cumulative mark of the online quizzes \\
2. & The students asked some problems appeared in using Edmodo, e.g. the instruction, icon, and \\
& facility \\
3. & The students requested more tasks in Edmodo not only outclass but also in class \\
4. & Few students felt difficulties in using Edmodo through their mobile phone and the lecturer \\
& suggested to use the personal computer to get more accessible area
\end{tabular}


The observation sheet indicated that the students enjoyed the blended learning program and eager to solve the problems appeared in the application used. They were addicted to do further online tasks that they might improve their vocabulary mastery.

Table 5. Questionnaire of Cycle 1

\begin{tabular}{|c|c|c|c|}
\hline No. & Statement & Yes \% & No $\%$ \\
\hline 1. & I used online learning media in my previous study & 76 & 24 \\
\hline 2. & I used blended learning in my previous study & 24 & 76 \\
\hline 3. & Blended learning is suitable technique to support English instruction & 91 & 9 \\
\hline 4. & $\begin{array}{l}\text { I got clear instruction and explanation in Edmodo as my online learning } \\
\text { media }\end{array}$ & 82 & 18 \\
\hline 5. & Before doing online tasks, I got clear instruction from my lecturer & 100 & 0 \\
\hline 6. & I feel comfort using Edmodo as the online learning application & 79 & 21 \\
\hline 7. & $\begin{array}{l}\text { Using the online application, I can ask and share information related to } \\
\text { the English material }\end{array}$ & 74 & 26 \\
\hline 8. & Through blended learning, I can develop more my vocabulary mastery & 91 & 9 \\
\hline 9. & In the online learning, I can practice more vocabulary tasks & 91 & 9 \\
\hline 10 . & In the online learning, I feel more confident practicing vocabulary tasks & 94 & 6 \\
\hline 11. & $\begin{array}{l}\text { The facility in the online media encourages me to keep developing } \\
\text { technical terms mastery }\end{array}$ & 91 & 9 \\
\hline 12. & I feel excited with the interactive feedback from the online quiz tasks & 86 & 14 \\
\hline 13. & $\begin{array}{l}\text { I feel excited using blended learning in developing technical terms } \\
\text { mastery }\end{array}$ & 97 & 3 \\
\hline
\end{tabular}

These quantitative data indicated the students' positive responses toward the blended learning program. $76 \%$ students did not use blended learning in the previous study. However, their responses gave a high percentage of their experience that they felt blended learning was useful to improve their vocabulary mastery with the range of percentage $74 \%$ to $100 \%$.

Table 6. Interview after the First Blended Learning

No.
1. The Edmodo is a little bit confusing for the first time due to the unclear written instruction, the
actions should be done to answer the questions, and the way to submit the quiz but then they
successfully struggle to use it.
2. The students are more discipline due to the locked deadline in the online tasks, but some do not
know the deadline that they cannot complete the tasks anymore.
The blended learning supports the vocabulary learning material by attaching the file, music,
picture, and video.
The technical terms mastery is improved that they can communicate more confidently however
5. The stimes the students misspelled in writing the technical terms
and serve the interactive feedback.
6. The students still need the face to face instruction to ensure that they have acquired the correct
understanding in the online instruction

The result of the interview showed that the students found difficulties in understanding the instructions and icons used in Edmodo. However, they tried more tasks more successfully and more punctually as there was a locked deadline set for the tasks submission. The additional learning media such as music, picture, and video attracted more motivation to complete the online tasks. Moreover, they shared that they still need the face to face instruction to ensure what they have got in the online class.

\section{e. Reflection}

In the Reflection step, overall steps were recalled to give feedback of evaluation needed to execute the improved design in Cycle 2. The data gathered reflected the following evaluation. 
Table 7. Evaluation of Cycle 1

\begin{tabular}{|c|c|}
\hline No. & Evaluation \\
\hline 1. & $\begin{array}{l}\text { It is important to train the students with the instruction, types of tasks, and facility of the online } \\
\text { platform }\end{array}$ \\
\hline 2. & $\begin{array}{l}\text { It is important to have vocabulary tasks allowing the students to have more rehearsal in writing } \\
\text { the technical words correctly without any misspellings. }\end{array}$ \\
\hline 3. & $\begin{array}{l}\text { It is important to encourage the students to do the online tasks through their personal computers } \\
\text { or laptops that allow the users to identify the clearer icons instead of the mobile phone when } \\
\text { problems with Edmodo facility (icon) occur. }\end{array}$ \\
\hline 4. & $\begin{array}{l}\text { Additional audio and visual materials need to be maintained that the students get clearer } \\
\text { description about certain technical terms in the daily life application }\end{array}$ \\
\hline 5. & $\begin{array}{l}\text { There must be rewards for students who can complete the online tasks punctually that they were } \\
\text { motivated to keep the deadline updated }\end{array}$ \\
\hline 6. & $\begin{array}{l}\text { It is important to maintain the use of face to face and online instruction proportionally since the } \\
\text { students still need the direct communication in the classroom to ensure their understanding. The } \\
\text { students need more face to face classes in Cycle } 1 \text {. }\end{array}$ \\
\hline
\end{tabular}

\subsection{Cycle 2}

a. Plan

In step, a set of improved blended learning was designed. It consisted of one online class and one face to face class delivered to all the students without separating the slow and fast learners as it was assumed that all the students have already had the equal learning speed from the separate tasks in Cycle 1. The tasks were in the forms of writing to improve the students' misspelling.

\section{b. Action}

The distribution of Action in Cycle 2 were:

Table 8. Action of Cycle 2

\begin{tabular}{lc}
\hline \multicolumn{1}{c}{ Online activity } & Group \\
\hline Text 6 & $\mathrm{C}$ \\
Video 2 & $\mathrm{C}$ \\
Summarizing the text & $\mathrm{C}$ \\
\hline \multicolumn{1}{c}{ Face to face activity } \\
\hline Students' written test & $\mathrm{C}$ \\
\hline
\end{tabular}

Here is the comparison between the test of Cycle 1 and Cycle 2

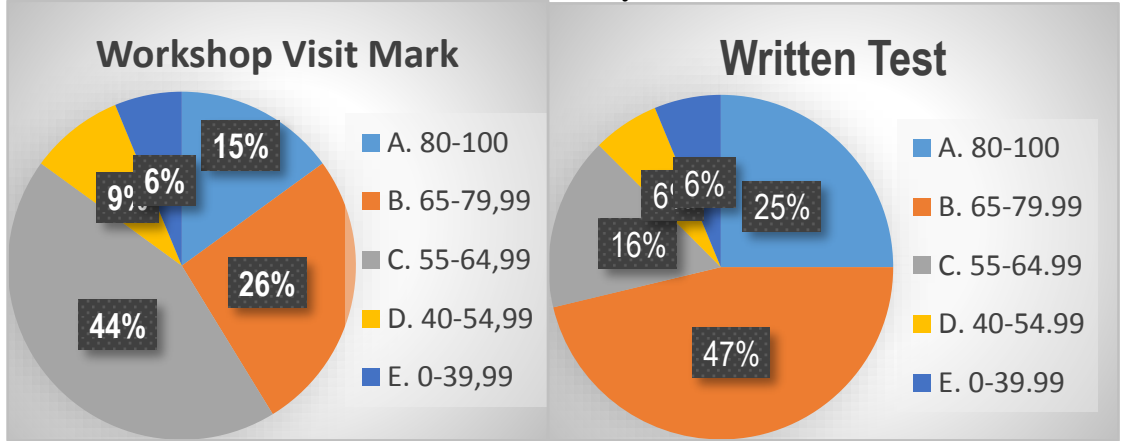

Figure 5. Workshop Visit Mark of cycle 2

Figure 6. Written Test Mark

The graphs showed that there was an improvement in the students' mark.

During the action, the students were given the second journal logs to write their comments in experiencing the second blended learning. 
Table 9. Journal Log of Cycle 2

\begin{tabular}{cl}
\hline No. & \multicolumn{1}{c}{ Responses } \\
\hline 1. & The students have been familiar with the icons and facilities of Edmodo \\
2. & The students got better mark in the summarizing online task because have known more technical \\
& terms \\
3. & The video was helpful to summarize the text \\
4. & The students could finish the online task punctually \\
5. & The students wrote the technical terms spelling more correctly
\end{tabular}

It showed there was no more misunderstanding on the facilities used in the Edmodo that all students could finish the online tasks more successfully and punctually. Secondly, they felt the video addition was more interesting and supported the tasks completion. Thirdly, the students' marks either in the online tasks or face to face class were better as the students thought they have known more technical terms.

\section{c. Observation}

In the observation step, the effects of the second blended learning were investigated from observation sheet, questionnaire, and the third interview presented as follows.

Table 10. Observation Findings of Cycle 2

\begin{tabular}{cl}
\hline No. & \multicolumn{1}{c}{ Findings } \\
\hline 1. & The students felt curious on the cumulative mark of the online tasks \\
2. & The students asked some problems appeared in using Edmodo, e.g. attaching file \\
3. & The students requested more tasks in Edmodo not only outclass but also in class \\
4. & The students communicated in English using technical terms more confidently \\
5. & The students asked the real example of the technical terms use in the daily life \\
\hline
\end{tabular}

The main phenomena found were that the students were more familiar with Edmodo application and used the technical terms more confidently in the face to face class such as they minimized the use of Indonesian and spoke more English technical terms in communication. This was supported by the following instruments.

Table 11. Questionnaire of Cycle 2

\begin{tabular}{|c|c|c|c|}
\hline No. & Statement & Yes \% & No $\%$ \\
\hline 1. & Blended learning is suitable technique to support English instruction & 91 & 9 \\
\hline 2. & $\begin{array}{l}\text { I got clear instruction and explanation in Edmodo as my online } \\
\text { learning media }\end{array}$ & 84 & 16 \\
\hline 3. & Before doing online tasks, I got clear instruction from my lecturer & 94 & 6 \\
\hline 4. & I feel comfort using Edmodo as the online learning application & 74 & 26 \\
\hline 5. & $\begin{array}{l}\text { Using the online application, I can ask and share information related } \\
\text { to the English material }\end{array}$ & 91 & 9 \\
\hline 6. & Through blended learning, I can develop more my vocabulary mastery & 94 & 6 \\
\hline 7. & In the online learning, I can practice more vocabulary tasks & 91 & 9 \\
\hline 8. & $\begin{array}{l}\text { In the online learning, I feel more confident practicing vocabulary } \\
\text { tasks }\end{array}$ & 94 & 6 \\
\hline 9. & $\begin{array}{l}\text { The facility in the online media encourages me to keep developing } \\
\text { technical terms mastery }\end{array}$ & 86 & 14 \\
\hline 10. & I feel excited with the feedback from the online tasks & 86 & 14 \\
\hline 11. & $\begin{array}{l}\text { I feel excited using blended learning in developing technical terms } \\
\text { mastery }\end{array}$ & 91 & 9 \\
\hline
\end{tabular}


Table 12. Interview after the Second Blended Learning

\begin{tabular}{cl}
\hline No. & \multicolumn{1}{c}{ Responses } \\
\hline 1. The Edmodo is no more confusing because the students have been familiar with the facilities, \\
instruction, and types of tasks \\
2. The students use the computer when they find difficult access in their mobile phone \\
3. The blended learning support the vocabulary learning material by attaching the file, music, \\
picture, and video \\
5. The technical terms mastery is improved that they can communicate more confidently \\
6. They students can identify the technical terms spelling more accurately \\
online instruction
\end{tabular}

\section{d. Reflection} evaluation.

Overall steps were recalled to give feedback on evaluation. The data gathered reflected the following

Table 13. Evaluation of Cycle 2

\begin{tabular}{|c|c|}
\hline No. & Evaluation \\
\hline 1. & $\begin{array}{l}\text { It is important to give more various tasks to improve the vocabulary development either in the } \\
\text { oral and written language skills }\end{array}$ \\
\hline 2. & $\begin{array}{l}\text { It is important to design the online learning not only outside class but also inside the class since } \\
\text { the students feel more challenged in doing the interactive tasks }\end{array}$ \\
\hline 3. & It is important to enrich the additional materials in the form of audio and visual media \\
\hline 4. & $\begin{array}{l}\text { It is important to find authentic material to give real example of the technical terms use in the } \\
\text { daily life }\end{array}$ \\
\hline 5. & $\begin{array}{l}\text { It is important to design face to face and online instruction proportionally so the students have } \\
\text { sufficient opportunity to ensure their understanding from the online instruction. }\end{array}$ \\
\hline
\end{tabular}

It can be reflected that the students enjoyed the action and improved their vocabulary mastery even though some problems may still appear due to the new platform they applied with. In an action research, continuous efforts to improve the instructional problems should be done. Due to the time limitation and the achieved improvement, this study ended in the Cycle 2.

The indicators of the improved vocabulary were seen in the better tasks achievement. Nation (2001) suggests the pre-requisite to the more challenging task designed to help achieve a learning goal, that improvement in numbers of mastered vocabulary are identified. To discuss the improvement in this research, the research findings taken from the data sources; interview, journal log, test, observation sheet, and questionnaire were interpreted.

\section{Interview}

The first interview was intended to dig up the reasons for low technical terms mastery in the mechanical engineering. The result was that they thought they had no sufficient time to develop their vocabulary mastery since the only had two credits in the English for mechanical engineering purposes and the learning media required some adaptations in order to facilitate the learning process.

The second interview was conducted after the first Action. The results were the students shared their problems in identifying the functions of Edmodo's icons and instructions that some students failed to complete the vocabulary tasks. Nevertheless, they were eager to learn the icons and instructions until they performed better achievement in the online tasks.

The third interview was conducted after the second Action. The results were the students felt easier in using the Edmodo application. When their mobile phone did work well, the students initiatively moved to their computer that had more access area. Moreover, they shared they could communicate more confidently using the technical terms and they improved their spelling more accurately proven in their written test result. 


\section{Journal Log}

The journal logs were taken home in order to write the students opinion more thoroughly. In the first journal $\log$, the students shared that they felt exited in blended learning even though they were still unfamiliar with the Edmodo facilities. They shared their ideal to get high marks in the test in terms of workshop visit to prove their vocabulary mastery improvement. In the second journal log the students thought they had no more misunderstanding on the icons of Edmodo that they could finish the online tasks more successfully and punctually. This improvement also affected the better results on the face to face tasks in terms of written test.

Test

The first test was delivered to the students to access their vocabulary mastery by assessing their performance in the mechanical engineering workshop visit. They were to describe the material types and the properties orally and then the result was compared to the mark from their mid-term test. The result was the students achieved an A increased from $15 \%$ to $25 \%$, a B increased from $26 \%$ to $47 \%$, a C decreased from $44 \%$ to $16 \%$, a D decreased from $9 \%$ to $6 \%$ and an $\mathrm{E}$ remained the same in $6 \%$.

The second test was delivered to the students to access their vocabulary in the form of written test that they could write the technical terms without the misspelling. The result was compared to the mark in the first Action and showed improvement on the students' mark as follows. Students achieved an A increased from $15 \%$ to $25 \%$, a B increased from $26 \%$ to $47 \%$, a C decreased from $44 \%$ to $16 \%$, a D decreased from $9 \%$ to $6 \%$ and an $\mathrm{E}$ remained the same in $6 \%$.

\section{Observation Sheet}

The observation was conducted in the face to face class and based on the lecturer's perception of the online tasks results. The first observation indicated that the students enjoyed the blended learning since they communicated more confidently using the technical terms even though they still used Indonesian quite often. In the second observation, it was found that they triggered to minimize Indonesian. It was assumed that they have mastered more technical terms during the first and the second actions.

\section{Questionnaire}

The first and second questionnaires were distributed to all the students to investigate the percentage of the student's perception. The data indicated the students' positive responses toward the blended learning program. Even though $76 \%$ students did not use blended learning in the previous study, their responses gave a high percentage of their experience that they felt blended learning was useful to improve their vocabulary mastery with the range of percentage $74 \%$ until $100 \%$.

\section{CONCLUSION}

The research emerged three conclusions. The blended learning encouraged the students to learn more various materials that support improving vocabulary mastery. The used mechanical engineering English workbook does not provide sufficient materials such as picture, authentic texts, or video. In certain cases, the students understand better the nature or definition of the technical terms by watching the video. By combining the classroom session into the online one, the lecturer is likely to link and put additional digital sources that the students are allowed to get more accesses.

The second, the blended learning encouraged the students to do various tasks and specifically in the online session, it provided interactive feedback. Even though in the first cycle the students were still confused about the icons, instructions, and the task submission mechanism, in the online class, the students showed better achievement in the second cycle. It is proven in the interview responses and the high percentage from the questionnaire.

The third, the blended learning effectively improved the vocabulary mastery. The students thought that face to face learning only was not as attractive as the online learning. However, the online learning 
only was worrying since the students still need the direct interaction to ensure their acquired knowledge. The students' achievement in workshop visit and written test prove the combination of face to face and online instruction encouraged the students to learn better.

\section{REFERENCES}

Arfaorafiee, N., \& Ameri-Golestan, A. (2015). Impact of blended learning on Iranian EFL learners' acquisition and retention of passive sentences. International Journal of Language Learning and Applied Linguistics World, 10(4), 14-29.

Azizan, F. Z. (2010). Blended learning in higher education institution in Malaysia. In Regional Conference on Knowledge Integration in ICT (pp. 454-466).

Basturkmen, H. (2006). Ideas and options in English for specific purposes. New Jersey: Lawrence Erlbaum Associates.

Burns, A. (2010). Doing action research in English language teaching: A guide for practitioners. New York: Routledge.

Charoenwet, S., \& Christensen, A. (2016). The effect of Edmodo learning network on students' perception, self-regulated learning behaviors and learning performance. In The 10th International MultiConference on Society, Cybernetics and Informatics (pp. 297-300).

Djiwandono, P. I. (2013). A blended learning approach to enhance college students' vocabulary learning. Electronic Journal of Foreign Language Teaching, 10(2), 210-220.

Henning, J. E., Stone, J. M., \& Kelly, J. L. (2009). Using action research to improve instruction: an interactive guide for teachers. New York and London: Taylor \& Francis Routledge.

Khalili, S., Tahririan, M. H., \& Bagheri, S. (2015). Vocabulary instruction through blended learning and multimedia software in Iranian ESP classes. Journal of English Language Teaching and Learning, $15,37-54$.

Lim, D. H., \& Morris, M. L. (2009). Learner and instructional factors influencing learning outcomes within a blended learning environment. International Forum of Educational Technology \& Society, 12(4), 282-293.

McNiff, J., Lomax, P., \& Whitehead, J. (2002). You and your action research project. London and New York: Hyde Publications.

Nation, I. S. P. (2001). Learning vocabulary in another language: learning Vocabulary in Another Language. Cambridge: Cambridge University Press.

Read, J. (2004). Research in teaching vocabulary. Annual Review of Applied Linguistics, 24, $146-161$. http://doi.org/10.1017/S0267190504000078

Tomal, D. R. (2010). Action research for educators (second ed). New York: Rowman \& Littlefield Publishers. 